\title{
Pengembangan Lembar Kerja Siswa (LKS) Berbasis Model Pembelajaran Kooperatif Tipe Student Teams Achievement Divissions (STAD) Pada Materi Statistika Kelas VIII
}

\author{
Wilibaldus Bhoke ${ }^{1}$, Maria Carmelita Tali Wangge ${ }^{2}$, Maria Rofina Soge ${ }^{3}$ \\ 1,2,3 Program Studi Pendidikan Matematika, Sekolah Tinggi Keguruan dan Ilmu Pendidikan Citra Bakti Ngada \\ JL. Trans Bajawa-Ende, Malanuza, Kec. Golewa, Kab. Ngada \\ wilibaldusbhoke87@gmail.com
}

\begin{abstract}
This research was used development research. Development research is a research that is useful for producing certain products (Sugiyono, 2013). The product which developed by this study was a Student Worksheet (LKS) which based on the Student Teams Achievement Division (STAD) The Type of Cooperative Learning on Statistics Material Model for Class VIII 05 Golewa Junior High School the LKS procedure is adjusted to the syntaxof the learning model. The development procedure was using ADDIE model development procedure which are consisting of five steps. The research subjects were students of class VIII 05 Golewa, Junior High School, totaling 5 people on the grounds of the corona virus (COVID 19). In this study, the data collection instruments were used interview or inreview guidelines, LKS (Student Work Sheet) assessment sheets and questionnaires. The data was collected, and analyzed by obtained from the validator, students and teacher assessment questionnaire. The obtained data to test the validity of the product, namely from material experts, got a percentage of $95 \%$ while from the expert design got a percentage of $80 \%$, which means that this product is suitable for using. Meanwhile, for testing the practicality of the product from the teacher questionnaire respons got a score of 4.7 and the student questionnaire respons got a score of 4.7. From the results above, it could be concluded that the product of the Student Worksheet is suitable for using.
\end{abstract}

Keywords: Student Worksheets, Development, Student Teams Achievement Divissions

\begin{abstract}
Abstrak
Jenis penelitian yang digunakan dalam penelitian ini adalah penelitian pengembangan. Penelitian pengembangan ialah penelitian yang berguna untuk menghasilkan produk tertentu. Produk yang dikembangkan dalam penelitian ini berupa Lembar Kerja Siswa (LKS) Berbasis Model Pembelajaran Kooperatif Tipe Student Teams Achievement Divissions (STAD) pada Materi Statistika Kelas VIII SMPN 05 Golewa prosedur LKS ini disesuaikan dengan sintaks dari model pembelajaran tersebut. Prosedur pengembangan yang digunakan yaitu prosedur pengembangan model ADDIE yang terdiri atas lima langkah. Subyek penelitian adalah siswa kelas VIII SMPN 05 Golewa, yang berjumlah 5 orang dengan alasan adanya virus corona (COVID 19). Dalam penelitian ini, instrumen pengumpulan data menggunakan pedoman wawancara atau interview, Lembar penilaian LKS (Lembar Kerja Siswa) dan angket. Setelah data dikumpulkan, selanjutnya data dianalisis yang diperoleh dari angket penilaian validator, siswa dan guru. Data yang diperoleh untuk menguji kevalidan produk yakni dari ahli materi mendapat persentase sebesar 95\% sedangkan dari ahli desain mendapatkan persentase $80 \%$ yang berarti poduk ini layak untuk digunakan. Sedangkan untuk menguji kepraktisan produk dari angket respon guru mendapat skor sebesar 4,7 dan angket respon siwa mendapat skor sebesar 4,7. Dari hasil yang telah diperoleh tersebut, maka dapat disimpulkan bahwa produk Lembar Kerja Siswa ini layak digunakan.
\end{abstract}

Kata Kunci: Lembar Kerja Siswa, Pengembangan, Student Teams Achievement Divissions

Copyright (c) 2021 Wilibaldus Bhoke, Maria Carmelita Tali Wangge, Maria Rofina Soge

$\triangle$ Corresponding author: Wilibaldus Bhoke

Email Address: wilibaldusbhoke78@gmail.com (Jl. Trans Bajawa-Ende, Malanuza, Kec. Golewa, Kab. Ngada)

Received 07 Desember 2020, Accepted 14 Februari 2021, Published 18 Februari 2021

\section{PENDAHULUAN}

Pendidikan mempunyai peranan dan tujuan yang sangat penting bagi kehidupan manusia. Pendidikan adalah proses panjang dan berkelanjutan untuk mentransformasi siswa menjadi manusia 
Pengembangan Lembar Kerja Siswa (LKS) Berbasis Model Pembelajaran Kooperatif Tipe Student Teams Achievement Divissions (STAD) Pada Materi Statistika Kelas VIII, Wilibaldus Bhoke, Maria Carmelita Tali Wangge, Maria Rofina Soge

yang sesuai dengan tujuan penciptaannya, yaitu bermanfaat bagi dirinya, bagi sesama, dan bagi alam semesta (Nuh, 2013). Pendidikan juga merupakan cara meningkatkan kualitas anak didik setelah melalui kegiatan-kegiatan belajar guna mencapai tertentu. Tujuan yang dimaksud adalah agar anak didik mampu mengembangkan potensi yang ada pada dirinya sehingga dapat berguna bagi diri sendiri maupun orang lain. Hal ini tercantum dalam Undang-undang Republik Indonesia Nomor 20 tahun 2003 tentang Sistem Pendidikan Nasional Pasal 1 yang menjelaskan bahwa, pendidikan ialah usaha sadar yang direncanakan dalam mewujudkan proses belajar agar siswa lebih aktif mengembangkan potensi dalam dirinya agar mempunyai kekuatan spiritual religius, pengendalian diri, kepribadian, kecerdasan, akhlak mulia, dan keterampilan yang dibutuhkan dirinya, lingkungan, bangsa dan negara. Pernyataan ini bisa dicapai melalui sistem pendidikan berupa pendidikan berbasis karakter.

Seseorang dikatakan belajar bila diasumsikan dalam diri orang tersebut terjadi suatu proses kegiatan yang mengakibatkan perubahan tingkah laku. Secara psikologis belajar merupakan suatu proses perubahan yaitu perubahan tingkah laku sebagai hasil interaksi dengan lingkungannya (Hudojo, 2001). Perubahan tingkah laku dari hasil belajar dapat diamati dan berlaku untuk waktu yang relatif lama. Perubahan tingkah laku yang berlaku dalam waktu yang relatif lama membutuhkan usaha sehingga orang yang belajar akan merubah dirinya dari tidak mampu menjadi mampu mengerjakan sesuatu. Tanpa usaha, meskipun terjadi perubah tingkah laku belum dikatakan belajar.

Pembelajaran adalah sesuatu yang dilakukan oleh siswa, bukan dibuat untuk siswa. Pembelajaran pada dasarnya merupakan upaya pendidik untuk membantu peserta didik melakukan kegiatan belajar. Tujuan pembelajaran adalah terwujudnya efisiensi dan efektivitas kegiatan belajar yang dilakukan peserta didik (Isjoni, 2013). Senada dengan hal tersebut Mulyasa, menyatakan bahwa guru harus berpacu dalam pembelajaran, dengan memberikan kemudahan belajar bagi seluruh peserta didik, agar dapat mengembangkan potensinya secara optimal (Mulyasa, 2014). Soedjadi menyatakan bahwa matematika yang diajarkan di pendidikan dasar dan menengah adalah matematika sekolah (Soedjadi, 2000). Matematika sekolah adalah unsur-unsur atau bagian-bagian dari matematika yang dipilih berdasarkan atau berorientasi kepada kepentingan pendidikan dan kepentingan untuk menguasai dan memanfaatkan teknologi di masa depan. Dalam hal ini, guru harus kreatif, profesional, dan menyenangkan, dengan memposisikan diri sebagai fasilitator yang selalu siap memberikan kemudahan, melayani peserta didik sesuai minat, kemampuan dan bakatnya. Untuk memenuhi tuntutan tersebut, guru harus memaksimalkan pembelajaran, serta menjadikan pembelajaran sebagai ajang pembentukan kompetensi dan perbaikan kualitas pribadi peserta didik.

Dalam dunia pendidikan, mata pelajaran matematika dianggap sulit oleh kebanyakan siswa. Yang menyebabkan siswa merasa kurang tertarik pada mata pelajaran matematika sehingga sedikit sekali peserta didik yang meminati mata pelajaran tersebut. Matematika merupakan mata pelajaran yang wajib dijelaskan disetiap jenjang pendidikan. Menurut Depdiknas "matematika berasal dari bahasa latin, mathanein atau mathema yang artinya "belajar atau hal yang dipelajari, sedangkan dalam bahasa 
Belanda, matematika disebut wiskunde atau ilmu pasti, yang kesemuanya berkaitan dengan penalaran" (dalam Susanto, 2014). Karena matematika sangat penting dalam proses pembelajaran, maka pendidik harus bisa mendidik dan melatih peserta didik sehingga mampu mencapai proses pembelajaran yang diinginkan

Selama melakukan observasi kelas pada tanggal 05 maret 2020, selama pembelajaran matematika berlangsung di kelas VIII SMPN 05 Golewa berpusat pada pendidik. Karena saat observasi, pendidik menjelaskan materi dengan pembelajaran langsung, diskusi dan contoh soal, yang menyebabkan respon anak didik kepada materi masih kurang. Dilihat pada saat anak didik mengerjakan latihan dari guru, sebagian peserta didik aktif, sebagian lainnya sibuk bercerita saat pendidik sedang memberikan materi pelajaran. Masalah lain, ditemukan dikelas VIII SMPN 05 Golewa ialah siswa sering berdiskusi dengan teman sebangku sehingga mereka lupa akan tugas yang diberikan guru.

Dilihat dari masalah di atas guru perlu merancang sebuah media pembelajaran yang tepat yaitu berupa penerapan LKS berdasarkan Model Pembelajaran Kooperatif Tipe STAD. Hal ini dilakukan karena LKS tersebut sangat membantu peserta didik dalam berpikir kritis serta dapat memecahkan masalah secara berkelompok. Pengunaan LKS ini dapat mendorong siswa dalam kegiatan pemecahan masalah. Lembar Kerja Siwa (LKS) mencakup langkah-langkah wajib dilakukan peserta didik dalam pencapaian indikator pembelajaran. Lembar Kerja Siswa (LKS) mampu menjadi sebagai panduan agar peserta didik mampu secara aktif dalam kegiatan belajar mengajar sekaligus mengarahkan anak didik untuk memahami materi pelajaran.

Pernyataan ini didukung melalui pendapat yang dikemukakan oleh Bhoke yang mengatakan bahwa pada dasarnya Lembar Kerja Siswa (LKS) berguna untuk tujuan peserta didik dalam bekerja secara individu (Bhoke, 2020). Dengan menggunakan Lembar Kerja Siswa (LKS) dapat mengingat sebuah konsep secara permanen. LKS sangat bermanfaat bagi siswa karena dengan adanya LKS, siswa dilatih untuk mencari sendiri dan mampu berpikir kritis. Daryanto \& Dwicahyono mengemukakan bahwa: (1) LKS adalah lembaran-lembaran berisi tugas yang harus dikerjakan oleh siswa; (2) Lembar kegiatan berisi petunjuk langkah-langkah untuk menyelesaikan tugas; (3) Tugastugas yang diberikan kepada siswa dapat berupa teori atau praktek; (4) Melakukan analisis kurikulum: SK, KD, Indikator dan Materi Pelajaran; (5) Menyusun peta kebutuhan LKS; (6) Menentukan judul LKS; dan (7) Menentukan alat penilaian (Daryanto \& Dwicahyono, 2014). Menurut Suyono \& Haryanto langkah-langkah menyusun suatu LKS dapat dilakukan sebagai berikut: 1) Mengkaji ulang dan mendalami materi yang akan dipelajari siswa mulai dari kompetensi dasar, indikator hasil belajar, dan sistematika keilmuan, 2)Mengidentifikasi jenis keterampilan proses yang akan dikembangkan pada saat mempelajari materi tersebut, 3)Menetapkan bentuk LKS yang sesuai dengan materi yang akan diajarkan, 4)Merancang kegiatan yang akan ditampilkan pada LKS sesuai dengan keterampilan proses yang akan dikembangkan., 5) Mengubah rancangan menjadi LKS dengan tata letak yang menarik, mudah dibaca dan digunakan, 6) Menguji coba LKS apakah sudah dapat digunakan siswa untuk melihat kekurangan-kekurangannya, 7) Merevisi LKS (Suyono \& Haryanto, 2015). 
Pengembangan Lembar Kerja Siswa (LKS) Berbasis Model Pembelajaran Kooperatif Tipe Student Teams Achievement Divissions (STAD) Pada Materi Statistika Kelas VIII, Wilibaldus Bhoke, Maria Carmelita Tali Wangge, Maria Rofina Soge

Statistika adalah salah satu materi dalam mata pelajaran matematika yang wajib dijelaskan ke peserta didikdijenjang satuan pendidikan SMP/MTs sesuai dengan Standar Isi Permendiknas NO. 22 Tahun 2006. Dari hasil wawancara bersama Ibu Maria Ngina, S.Pd, yakni guru mata pelajaran matematika di SMP Negeri 05 Golewa, mengatakan bahwa siswa mengalami kesulitan dalam belajar konsep statistika. Banyak ditemukan siswa yang belum mengerti materi statistika. Sebagian dari mereka kesulitan dalam memahami mean dan nilai tengah. Masih banyak siswa yang merasa sulit ketika diberikan soal cerita yang panjang dan juga kebanyakan siswa kurang teliti dalam menyelesaikan soal dengan menggunakan data yang cukup banyak. Permasalahan di atas membuat guru selaku faktor utama dalam pembelajaran diharapkan bisa membuat situasi untuk memotivasi peserta didik dalam kelas. Oleh karena itu, dibutuhkan model pembelajaran yang bisa membuat anak didik ikut dalam belajar dan saling berdiskusi. Skill peserta didik yang berbeda dapat digunakan dalam menyatukan anak didik dalam situasi belajar untuk saling berinteraksi. Model pembelajaran mejadikan peserta didik untuk dimanfaatkan skill adalah model pembelajaran yang kooperatif. Menururt Trianto, pembelajaran kooperatif adalah satu organisasi siasat mengajar yang melibatkan peserta didik bersama berkelompok dalam mencapai suatu tujuan bersama. Pada pembelajaran kooperatif, anak didik saling bekerjasama dan mempunyai satu tujuan (Trianto, 2011).

Kerjasama antar siswa dalam kelompok tersebut akan diterapkan pada penelitian yang akan dilakukan. Beberapa jenis model pembelajaran kooperatif salah satunya ialah model pembelajaran kooperatif tipe Student Teams Achievement Divissions (STAD). Model pembelajaran kooperatif tipe Student Teams Achievement divissions (STAD) ialah pendekatan Cooperative Learning yang fokus pada komunikasi antara anak didik agar mendukung dalam mengatasi materi pelajaran.

Model Pembelajaran kooperatif tipe Student Teams Achievement Divissions (STAD) sangat cocok digunakan di SMP. Model ini diberikan peluang kepada semua anak didik agar lebih aktif dalam proses belajar mengajar. Pembelajaran kooperatif tipe Student Teams Achievement Divissions (STAD) adalah model pembelajaran kooperatif yang melibatkan peserta didik 4-5 anak didik secara berbeda,dan merupakan gabungan sesuai prestasi, jenis kelamin, dan ras, dimulai dari penjelasan tujuan belajar, penjelasan materi, diskusi, tes individu dan hadiah kelompok. Menurut Agus, pembelajaran kooperatif adalah konsep yang lebih luas meliputi semua jenis kerja kelompok termasuk bentuk-bentuk yang lebih dipimpin oleh guru atau diarahkan oleh guru, dimana guru menetapkan tugas dan pertanyaan-pertanyaan serta menyediakan bahan-bahan dan informasi yang dirancang untuk membantu peserta didik menyelesaikan masalah yang dimaksud (Agus, 2009). Guru biasanya menetapkan bentuk ujian tertentu pada akhir tugas. Sedangkan menurut Lie (dalam Isjoni, 2014), cooperative learning dengan istilah pembelajaran gotong royong, yaitu sistem pembelajaran yang memberi kesempatan kepada peserta didik untuk bekerja sama dengan siswa lain dalam tugas-tugas yang terstruktur. Mohamad Nur menjelaskan bahwa model pembelajaran kooperatif tipe STAD, Siswa ditempatkan dalam kelompok belajar yang beranggotakan 4-5 orang siswa yang merupakan 
campuran dari siswa yang kemampuan akademiknya berbeda sehingga dalam setiap kelompok terdapat siswa yang berprestasi rendah, sedang dan tinggi atau variasi jenis kelamin, kelompok ras dan etnis atau kelompok sosial lainnya (Nur, 2008). Ibrahim, dkk menyatakan model pembelajaran kooperatif tipe STAD adalah suatu pembelajaran yang mengacu pada belajar kelompok siswa menyajikan informasi dengan menggunakan presentasi verbal atau teks, dimana di dalamnya siswa diberikan kesempatan untuk melakukan kolaborasi dan elaborasi dengan teman sebayanya dalam bentuk diskusi kelompok untuk memecahkan suatu masalah (Ibrahim \& dkk, 2000).

Sejalan dengan hal tersebut di atas dalam Model Pembelajaran kooperatif tipe STAD dapat membangun pemikiran konstruktif, meningkatkan semangat dan motivasi belajar yang pada akhirnya juga dapat meningkatkan minat belajar siswa dalm proses belajar mengajar. STAD merupakan singkatan dari Student Team Achievement Division. Pembelajaran tipe STAD ini dikembangkan oleh Robert Slavin dan kolega-koleganya di Universitas John Hopkin, dan salah satu tipe kooperatif yang menekankan pada adanya aktivitas dan interaksi diantara siswa untuk saling memotivasi dan saling membantu dalam menguasai materi pelajaran guna mencapai prestasi yang maksimal.

Slavin mengungkapkan bahwa dalam pembelajaran kooperatif tipe STAD, para siswa dibagi dalam tim belajar yang terdiri atas empat orang yang berbeda-beda tingkat kemampuan, jenis kelamin, dan latar belakang etniknya (Slavin, 2005). Guru menyampaikan pelajaran, lalu siswa bekerja dalam tim mereka untuk memastikan bahwa semua anggota tim telah menguasai pelajaran. Selanjutnya, semua siswa mengerjakan kuis mengenai materi secara mandiri, dimana saat itu mereka tidak diperbolehkan untuk saling membantu satu sama lain. Sementara itu menurut Rusman, STAD adalah model pembelajaran kooperatif yang sangat tepat untuk mengajarkan materi-materi yang berkaitan dengan penerapan matematika (Rusman, 2012). Dalam STAD, siswa dibagi menjadi kelompok beranggotakan empat atau lima orang yang beragam kemampuan dan jenis kelamin.

Jika siswa sudah memiliki semangat untuk belajar maka siswa tersebut akan mudah menyelesaikan soal-soal dalam LKS tersebut. Berangkat dari semua permasalahan di atas maka diambil solusi yang tepat berupa Pengembangan LKS dengan model pembelajaran kooperatif tipe STAD yang telah dirancang dan digunakan oleh semua siswa tersebut. Lembar Kerja Siswa (LKS) adalah lembaran-lembaran berisi tugas yang harus dikerjakan oleh siswa (Depdiknas, 2008). LKS disusun bukan dipakai sebagai buku referensi melainkan dipakai sebagai media belajar dimana siswa membaca suatu permasalahan dan mereka mengerjakan tugas atau menjawab soal dengan berdikusi dalam kelompok.

Lembar Kegiatan Siswa memuat sekumpulan kegiatan mendasar yang harus dilakukan oleh siswa untuk memaksimalkan pemahaman sesuai dengan indikator pencapaian hasil belajar yang harus dicapai. Dengan adanya LKS akan membantu guru dalam melaksanakan pembelajaran.

Dengan tujuan utama adalah untuk menghasilkan Lembar Kerja Siswa (LKS) Berbasis Model Pembelajaran Kooperatif Tipe Student Teams Achievement Divissions (STAD) Pada Materi Statistika Kelas VIII SMPN 05 Golewa, serta mengetahui kevalidan yang ditentukan dari hasil uji ahli materi 
Pengembangan Lembar Kerja Siswa (LKS) Berbasis Model Pembelajaran Kooperatif Tipe Student Teams Achievement Divissions (STAD) Pada Materi Statistika Kelas VIII, Wilibaldus Bhoke, Maria Carmelita Tali Wangge, Maria Rofina Soge

dan desain serta mengetahui kepraktisan yang diambil dari hasil uji angket respon siswa dan respon guru.

\section{METODE}

Jenis penelitian ini merupakan penelitian pengembangan., karena dalam penelitian mengembangkan LKS dengan Model Kooperatif tipe STAD pada materi Statistika. Subyek dalam penelitian ini adalah siswa kelas VIII SMPN 05 Golewa tahun ajaran 2019/2020. Model pengembangan yang digunakan dalam penelitian ini adalah model pengembangan ADDIE. Menurut Mulyatiningsih, terdiri dari lima tahapan yaitu 1) Analysis (Proses mendefinisikan apa yang akan dipelajari oleh peserta didik yang meliputi analisis kebutuhan, analisis kurikulum dan analisis karakteristik peserta didik), 2) Design (Menentukan judul LKS, penulisan draft LKS, menyiapkan buku referensi, menyusun peta kebutuhan LKS, Menyusun desain LKS), 3) Development (Memproduksi Lembar Kerja Siswa (LKS) yang akan digunakan dalam proses pembelajaran), 4) Implementation (melakukan uji coba pada sekolah yang dijadikan sebagai tempat peneitian serta membagi angket respon kepada siswa), 5) Evaluation (Melakukan revisi sebagai bentuk penyempurnaan produk) (Mulyatiningsih, 2011). Jenis data yang digunakan dalam penelitian ini ada dua yaitu data kualitatif dan data kuantitatif. Data kuantitatif diperoleh dari penyebaran angket. Sedangkan data kualitatif diperoleh dari hasil wawancara guru matapelajaran matematika dan respon siswa. Metode pengumpulan data yang digunakan adalah menggunakan metode observasi, lembar validasi dan metode angket. Sedangkan analisis data secara deskrptif.

\section{HASIL DAN DISKUSI}

\section{Hasil Penelitian}

Hasil dari penelitian pengembangan ini ialah menghasilkan LKS Berbasis Model Pembelajaran Kooperatif Tipe STAD pada Materi Statistika Kelas VIII SMPN 05 Golewa. Pengembangan LKS ini menggunakan pengembanggan ADDIE yang terdiri dari:

\section{Tahap Analisis (Analyze)}

Pada tahap ini peneliti mengkaji terhadap Kompetensi Dasar, Indikator pembelajaran sesuai dengan tuntutan perkembangan kurikulum. Hasil pengkajian tersebut diperoleh bahwa kompetensi dasar serta indikator pembelajaran telah sesuai dengan perkembangan kurikulum yang digunakan disekolah untuk dilakukan pengembangan berupa LKS.

\section{Tahap Desain (Design)}

Peneliti menentukan draf Lembar Kerja Siswa (LKS) serta mengumpulkan refrensi-refrensi mengenai materi yang akan disajikan di dalam LKS.

\section{Tahap Pengembangan (Development)}

Tahap pengembangan ini artinya peneliti merealisasikan LKS. Hasil pengembangan LKS Berbasis Model Pembelajaran Kooperatif Tipe STAD adalah sebagai berikut: 
1) Cover

Pada produk pengembangan LKS ini mempunyai Cover depan. Desain cover depan terdiri dari judul, tulisan materi serta tempat untuk satuan pendidikan, mata pelajaran serta kelas atau semester. Gambar tampilan Cover dapat dilihat pada gambar 1 di bawah ini.

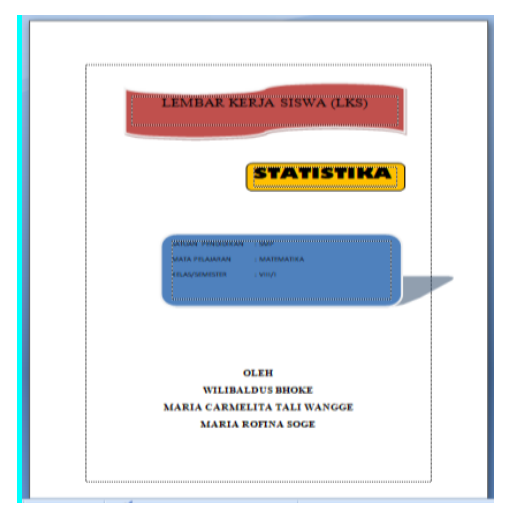

\section{Gambar 1 Desain cover depan}

2) Kata Pengantar

Tujuan dibuatnya kata pengantar ini yakni untuk menyampaikan ucapan rasa syukur dan terimkasih kepada semua pihak yang turut ambil bagian dalam penulisan ini. Kata pengantar dibuat dalam bentuk yang sederhana seperti pada gambar 2 dibawah ini.

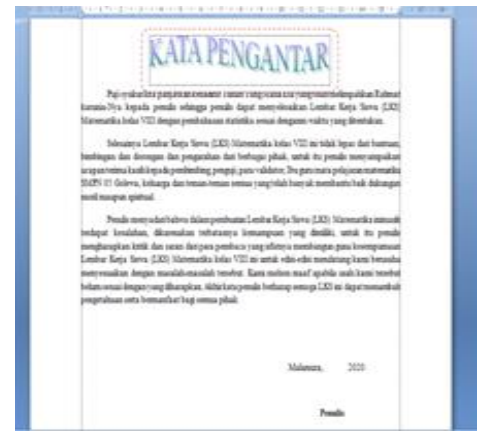

\section{Gambar 2 Kata Pengantar}

\section{Tahap Implementasi I (Implentation)}

Tahap ini, peneliti melakukan uji coba kepada kedua ahli sebagai validator. Hasil dari uji coba ini berupa saran atau masukan dari para ahli.

\section{Tahap Evaluasi I (Evaluation)}

\section{Tahap Implementasi II (Implementation)}

Pada tahap ini, peneliti memberikan lembaran kuisioner atau instrumen kepada validator ahli konten dan validator ahli desain.

\section{Tahap Evaluasi II (Evaluation)}


Pengembangan Lembar Kerja Siswa (LKS) Berbasis Model Pembelajaran Kooperatif Tipe Student Teams Achievement Divissions (STAD) Pada Materi Statistika Kelas VIII, Wilibaldus Bhoke, Maria Carmelita Tali Wangge, Maria Rofina Soge

Agar dapat mengetahui pengunaan produk pengembangan LKS maka peneliti melakukan revisi berdasarkan komentar para ahli dari uji coba yang dilakukan dengan memberikan lembar kuisioner kepada para ahli.

\section{Penyempurnaan Produk}

Setelah melakukan pengujian ke beberapa para ahli yakni ahli materi dan ahli desain dan mendapat beberapa masukan serta revisi pada produk Pengembangan LKS Berbasis Model Pembelajaran Kooperatif Tipe STAD dan pada akhirnya produk LKS layak digunakan.

\section{Pembahasan}

Menurut Nieeven validitas suatu perangkat pembelajaran dilihat dari apakah berbagai komponen dari perangkat pembelajaran tersebut terkait secara konsisten antara satu dengan yang lainnya (Nieveen, 1999). Untuk mengetahui validitas suatu instrumen atau perangkat perlu dilakukan pengujian. Pada tahap ini, peneliti melakukan perhitungan skor untuk mengetahui kevalidan LKS. Berdasarkan perhitungan dengan menggunakan rumus diperoleh hasil kevalidan produk untuk ahli materi sebesar 95\% tergolong dalam kategori valid dan tidak perlu revisi. Sedangkan perhitungan untuk ahli desain berdasarkan rumus diperoleh $80 \%$ tergolong dalam kategori valid. Sedangkan untuk menguji kepraktisan diperoleh dari angket respon guru menggunakan rumus diperoleh hasil 4,7\%, dan angket respon siswa diperoleh hasil $4,7 \%$.

Berikut merupakan tabel hasil uji kevalidan dan uji kepraktisan produk LKS Berbasis Model Pembelajaran Kooperatif Tipe STAD seperti pada tabel 1 dan tabel 2 dibawah ini.

Tabel. 1. Hasil Uji Validitas Produk LKS Berbasis Model Pembelajaran Kooperatif Tipe STAD

\begin{tabular}{|c|l|c|l|}
\hline No & \multicolumn{1}{|c|}{ Nama } & Skor/persentase & \multicolumn{1}{c|}{ Kriteria } \\
\hline 1 & Ahli Materi & $95 \%$ & Sangat Layak \\
\hline 2 & Ahli Desain & $80 \%$ & Layak \\
\hline
\end{tabular}

Tabel 2. Hasil uji kepraktisan produk LKS Berbasis Model Pembelajaran Kooperatif Tipe STAD

\begin{tabular}{|c|l|c|l|}
\hline No & \multicolumn{1}{|c|}{ Nama } & Skor/persentase & \multicolumn{1}{c|}{ Kriteria } \\
\hline 1 & Respon guru & 4,7 & Baik sekali \\
\hline 2 & Respon siswa & 4,7 & Baik sekali \\
\hline
\end{tabular}

\section{KESIMPULAN}

Berdasarkan hasil dan pembahasan di atas diperoleh kesimpulan 1) Lembar Kerja Siswa Berbasis Model Pembelajaran Kooperatif Tipe Student Teams Achievement Divissions (STAD) Pada Materi Statistika dinyatakan layak digunakan oleh siswa dengan melihat hasil perhitungan uji ahli materi, ahli desain, siswa serta guru terhadap LKS berbasis model pembelajaran kooperatif tipe Student Teams Achievement Divissions (STAD) Pada materi statistika. Skor dari ahli materi yaitu 95\% dan ahli desain $80 \%$. 2). Hasil uji coba produk pada kelompok kecil, berupa pemberian LKS 
berbasis model pembelajaran kooperatif tipe Student Teams Achievement Divissions (STAD) pada siswa dengan skor angket respon siswa sebesar 4,7 dan skor angket respon guru sebesar 4,7 dengan kriteria sangat layak untuk dipergunakan.

\section{UCAPAN TERIMA KASIH}

Pada kesempatan ini penulis menyampai rasa syukur dan terimakasih kepada semua pihak yang telah membantu dalam menyelesaikan artikel ini. Terlebih khusus kepada kepala SMPN 4 Golewa beserta siswa-siswi kelas VIII yang telah meluangkan waktu selama penulis mengambil data. Juga kepada ibu Maria Ngina Ghiko, S. Pd selaku ahli materi yang telah banyak memberikan masukan terhadap penyempurnaan produk LKS ini

\section{REFERENSI}

Agus, S. (2009). Cooperative Learning, Teori dan Aplikasi PAIKEM. Surabaya: Pustaka Belajar.

Bhoke, W. (2020). Teori dan Implementasi Pembelajaran Matematika dengan Media LKS. Makassar: Yayasan Barcode.

Daryanto, \& Dwicahyono, A. (2014). Pengembangan Perangkat Pembelajaran (Silabus, RPP, PHB, Bahan Ajar). Yogyakarta: Gava Media.

Depdiknas. (2008). Pengembangan Bahan Ajar. Jakarta: Depdiknas.

Hudojo, H. (2001). Belajar Pengembangan Kurikulum dan Pembelajaran Matematika. Malang: UM.

Ibrahim, M., \& dkk. (2000). Pembelajaran Kooperatif. Surabaya: University Press.

Isjoni. (2013). Pembelajaran Kooperatif: Meningkatkan Kecerdasan Komunikasi antar Peserta Didik. Yogyakarta: Pustaka Belajar.

Isjoni. (2014). Cooperative Learning Mengembangkan Kemampuan Belajar Berkelompok. Bandung: Alfabeta.

Mulyasa, H. E. (2014). Pengembangan dan Implementasi Kurikulum 2013. Bandung: Remaja Rosdakarya.

Mulyatiningsih. (2011). Evaluasi Proses Suatu Program. Jakarta: Bumi Aksara.

Nieveen, N. (1999). Prototyping to Research Product Quality from Design Approaches And Tools In Education And Training. Nederlands: Kluwer Academy Publisher.

Nuh, M. (2013). Nuh, Muhammad. (2013). Menyemai Kreator Peradaban. Jakarta: Zaman. Jakarta: Zaman. 
Pengembangan Lembar Kerja Siswa (LKS) Berbasis Model Pembelajaran Kooperatif Tipe Student Teams Achievement Divissions (STAD) Pada Materi Statistika Kelas VIII, Wilibaldus Bhoke, Maria Carmelita Tali Wangge, Maria Rofina Soge

Nur, M. (2008). Pembelajaran Kooperatif. Surabaya: Pusat SAINS dan Matematika.

Rusman. (2012). Model-model Pembelajaran: Mengembangkan Profesionalisme Guru (2nd ed.). Jakarta: Rajawali Pers.

Slavin, R. E. (2005). Cooperative Learning: Teori, Riset dan Praktik. Bandung: Nusa Media.

Soedjadi, R. (2000). Kiat Pendidikan Matematika di Indonesia. Konstatasi Keadaan Masa Kini Menuju Masa Depan. Jakarta: Direktorat Jenderal Pendidikan Tinggi Departemen Pendidikan Nasional.

Sugiyono. (2013). Metode Penelitian Pendidikan Pendekatan Kuantitatif, Kualitatitf, dan $R \& D$. Bandung: Alfabeta.

Susanto. (2014). Teori Belajar dan Pembelajaran di Sekolah Dasar. Jakarta: Kencana Prenada Media Group.

Suyono, \& Haryanto. (2015). Implementasi Belajar dan Pembelajaran. Bandung: PT Remaja Rosdakarya.

Trianto. (2011). Mendesain Model Pembelajaran Inovatif-Progresif. Jakarta: Kencana Prenada Media Group. 